\title{
Varieties of English in current English language teaching
}

\author{
Markus Bieswanger \\ University of Flensburg, Auf dem Campus 1, 24943 Flensburg, Germany \\ markus.bieswanger@uni-flensburg.de
}

\section{Introduction}

The systematic description of varieties of English, native and non-native, is steadily gaining momentum in contemporary sociolinguistics (c.f., e.g., Kortmann and Schneider 2004, cf. also Schneider 1997a,b; Labov, Ash and Boberg 2005; Burridge and Kortmann 2008; Kortmann and Upton 2008; Mesthrie 2008; Schneider 2008). English has long been identified to be a pluricentric language (Clyne 1991), and more recently linguists have been paying increasing attention to the use of English as a Lingua Franca (ELF), as there is widespread agreement about the fact that "the vast majority of verbal exchanges in English do not involve any native speakers at all" (Seidlhofer 2005a: 339, b; cf. also Jenkins 2005). Cook (2003) points out that it is communicative language teaching, an approach based on the introduction of the concept of communicative competence by Hymes (1972), that still remains "the dominant orthodoxy in progressive language teaching" today (Cook 2003: 36). This also means that 21st century speakers and learners of English need to be linguistically, sociolinguistically and pragmatically equipped to be able to communicate with native and non-native speakers of English from various regional, social and cultural backgrounds (Bieswanger 2007: 405). ELT, broadly defined by the Oxford University Press ELT Journal as "the field of teaching English as a second or foreign language", is thus currently facing new challenges in a changing and increasingly globalized world. The issue of which varieties should be learned by non-native learners of English and the question of acceptability of 
linguistic variation in ELT have become widely discussed topics in academic writing about ELT and are everyday issues for contemporary language teachers (cf. Görlach 1999; McArthur 2001; Gnutzmann 2005). The increasing importance of different Englishes particularly native varieties other than British and American English, the New Englishes and ELF - however, appears to be still only marginally reflected in ELT curricula and teaching material. This paper presents an analysis of a current German secondary school ELT curriculum, accompanying teaching material and selected German university programs for prospective teachers of English. The present study addresses a number of variation-related questions, such as "How important should varieties be in ELT?" and "What is the role of ELF?" These questions (further delineated in section 2 below) are equally relevant for ELT in countries like Germany, where English is taught as a foreign language, and multilingual countries such as South Africa and India, where English has a whole range of different functions.

\section{Why more varieties of English in ELT?}

The original motivation for this paper stems from many years of teaching English to adults in the context of evening classes, intended to refresh the knowledge of English they had acquired in secondary school. The intermediate and advanced learners of English in my classes, who had all received between five and nine years of English foreign language education in German secondary schools, frequently reported frustrating experiences they had had in English-speaking environments at home and abroad. They often complained about situations in which their native or non-native interlocutors had been speaking "so strangely" [i.e., employing a variety of English with which they were not familiar] that their "school English" [i.e., the English they had learned in secondary school] did not enable them to take part in certain English-language conversations. More precisely, these learners of English could not cope in situations in which they either had to speak English in a native-speaking context or use ELF with other non-native speakers of English. The conversation failed because their interlocutors did not speak the type of standardized English they had themselves learned in secondary school, but used a variety they considered "strange". Additionally, the encounter with more or less intelligible varieties of English obviously added to the so-called "culture shock" generally caused by foreign environments. The above reports indicate that many years of English foreign language education in secondary school had not prepared these 
speakers for the sociolinguistic reality in an increasingly globalized world and had failed to create any kind of awareness of the considerable regional variation in the use of English. This violates the basic principle of English language and foreign language education as formulated in Klippel and Doff's (2007: 36) handbook of English foreign language education: "school is supposed to prepare children and teenagers for successfully coping with their lives" (my translation).

In the course of the twentieth century, English has become a world language and the undisputed global lingua franca, and as a result the ability to effectively communicate in English is currently considered a skill that enables individuals to deal with the demands and challenges of everyday life in a globalized world (Centre for Applied Linguistics 2006; Klippel and Doff 2007: 36; McArthur 2001: 1). Similar demands for a sound command of English are found in the curriculum for the so-called Realschule in Bavaria, the intermediate of the three types of secondary schools within the state of Bavaria, Germany. The following translated passage from the introductory section of the curriculum for the subject English at the Bavarian Realschule defines the aims of English foreign language education at the Realschule:

Internationally, English is the most important second language and lingua franca. In many areas of interaction - in the economy and technology, in science and the arts, in tourism and sports - the English language is a natural means of communication. A sound knowledge of English is thus indispensible for Realschul-graduates, from both a private as well as a job perspective. [...] English language education at the Realschule attaches particular importance to the creation of young people who are open-minded and able to communicate.

(BMUK 2000-2003: 52, my translation)

The curriculum focuses on the ability to communicate and has to be placed in the tradition of communicative language-learning, which is still widely agreed to be the dominant approach in ELT, despite recent movements such as focus on form (cf. Doughty and Williams 1998; Cook 2003: 36). In light of the above-mentioned reports by the learners in my evening classes, the demands for communicative competence, in both ELT literature as well as the 
curriculum referred to above, lead to two main research questions that will be addressed in this paper:

(i) How can current ELT (better) help to produce graduates who are able to communicate in as many situations as possible?

(ii) What role can sociolinguistic aspects play in this context?

These questions are themselves based on two main developments. As I have mentioned above, communicative competence has been the main aim of ELT since the 1970s, and during the same period the situation of English in the world has changed. Today, the vast majority of English speakers/users worldwide are non-native speakers/users of English, and even most native speakers do not speak the widely taught but highly generalized varieties usually labeled "British English" and "American English". This fact is essentially undisputed, although it is extremely difficult to give reliable numbers for speakers/users of English in the world. Gnutzmann and Intemann (2005) state in the introduction to their seminal volume on The Globalization of English and the English Language Classroom:

Facing these uncertainties, it becomes obvious that counting speakers is nearly impossible and that all data available is largely, if not exclusively, based on estimates. [...] If the numbers of speakers of English as a Native Language (ENL) is uncertain, then the estimates for speakers of English as a Second Language (ESL) are even more so. [...] Estimating the number of speakers of English as a Foreign Language (EFL) cannot be anything more than a good guess.

(Gnutzmann and Intemann 2005: 13)

The most difficult task in this context is the definition of what constitutes a speaker or user of English. Quantitative estimates of speakers/users of English vary considerably because "the terms 'speaker' and 'user' are not clearly defined", and because there is no agreement among linguists as to "the minimum level of proficiency that can be counted as English-speaking, using or -knowing" (Bieswanger and Becker 2008: 34). Estimates put the number of nativespeakers of English between 300 and 400 million (Viereck, Viereck and Ramisch 2002: 242; Crystal 2003: 65) and the number of non-native-speakers at a range from several hundred million to more than two billion (Bieswanger and Becker 2008: 34). Whatever the exact 
numbers, it is undisputed that the English language is a truly global language that is used in a vast number of countries and territories for a myriad of different functions. The linguistic variation that accompanies the geographical distribution and functional range of English is at least partly due to the fact that "no other language has ever been put to so many uses so massively by so many people in so many places" (McArthur 1998: 54).

It was stated above that the majority of native-speakers do not actually speak the varieties labeled as "British English" or "American English" that are usually taught to foreigners. The Received Pronunciation (RP) accent, often associated with - or by non-linguists even understood to be identical to - "British English", is one example of a widely taught variety which is only spoken by a very small percentage of native-speakers of English. In an interview, Crystal (2002: 20) summed up the current status of RP as follows:

So RP has only ever been spoken at most by about five per cent of the population of England. And don't forget that it is England we are talking about. We're not talking about Wales, where RP was never an important element, nor Scotland, nor Northern Ireland, let alone Ireland as a whole. But even in England, 50 years ago, only about five per cent of the people would have spoken RP, and that figure is now down, I imagine, to less than two per cent ..."

(Crystal 2002: 20)

Speakers of RP are thus only a small minority of English-speakers in Britain and a tiny fraction of all native-speakers of English worldwide. We find a similar situation when we look at standard national varieties of English. We no longer only distinguish between British Standard English (BrSE) and American Standard English (AmSE), which are only spoken by a minority of people in Britain and the United States, but also a number of other standard national varieties of English plus, of course, a multitude of other geographical and social varieties. Even without taking into account the non-native speakers of English, the linguistic landscape had changed dramatically by the end of the 20th century. McArthur (2001: 1) discusses the situation from an ELT perspective and concludes:

... these two 'traditional' Standard Englishes [i.e. BrSE and AmSE] co-exist with many other Englishes in the UK, the US, and elsewhere as part of a 'world English' or 
within a range of 'world Englishes', and further Standard Englishes have begun to assert themselves more potently than before, in for example Australia (AusSE), Canada (Can SE), and the Philippines (PhilSE).

(McArthur 2001: 1)

We have seen that the majority of English-speakers/users are now non-native users of the language, that there is a huge diversity of varieties of English in use today and that even native speakers of English rarely speak the highly generalized traditional Standard Englishes. It is, however, not only the proportion of native speakers to non-native speakers or RP speakers to non-RP speakers that should be considered; it is a whole set of new or changing attitudes and parameters that should lead to a rethinking of educational policies in ELT and a strengthened role of varieties in the classroom. Three developments are particularly relevant, of which only one is directly linked to globalization: Firstly, there is an ongoing process of strengthening of regional and social varieties in areas where English is traditionally the native language of the majority of the population. Particularly in the United Kingdom there seems to be an increasing acceptance of regional and social varieties in society, going hand-in-hand with devolution and a strengthening of the regions. This is reflected, for example, in changing language policies in the media, such as the hiring of non-RP-speaking announcers by the BBC, and an increasing interest of linguists in these varieties (cf. Hughes, Trudgill and Watt 2005). Secondly, there is a growing self-confidence of previously often stigmatized native and non-native national and regional varieties outside the UK and the USA, such as Australian English, New Zealand English, South African English and Indian English to name but a few. The traditional prestige and standard varieties are no longer considered target norms by many speakers of these national and regional varieties, resulting in a decreasing influence of the traditional norms. The increasing self-confidence and independence of these varieties is reflected in and probably to a certain extent fostered by the systematic linguistic description of these varieties (cf. Hickey 2004; Kortmann and Schneider 2004). Thirdly, due to globalization and the availability of affordable means of long-distance communication and transportation, there is growing contact between learners of English and native-speakers on the one hand, and between learners of English from different backgrounds on the other. This leads to the increased use of ELF and has lead some scholars to argue in favor of abandoning the native-speaker standard altogether (Jenkins 2005; Seidlhofer 2005b). 
These changes, however, do not only warrant questions with respect to norms but have lead ELT researchers to discuss a whole range of consequences for ELT. Gnutzmann and Intemann (2005) demand an increased consideration of varieties of English in ELT, particularly as far as receptive abilities and intercultural skills are concerned:

As a result of globalisation the function of English as an international tool for communication needs rethinking in the English language classroom. This does not only include linguistic skills to understand various kinds of accents and to be understood by others, but it also includes knowledge of other cultures which provides the learners with the ability to respond adequately to problems arising from cultural differences between the participants in international communication.

(Gnutzmann and Intemann 2005: 20)

Görlach (1999: 18) also demands that "students' receptive competence (in reading and listening comprehension) should be trained at an early age...", and adds that the confrontation with varieties "could and should include texts from the periphery". Seidlhofer (2005b: 170), on the other hand, raises the criticism that "the control over the norms and how it [i.e. English] 'should be used' is still assumed to rest with the minority of its speakers, namely English native speakers", and argues for a "questioning of established authority" in favor of ELF. However, I would not consider ELF a suitable norm for ELT at the present stage, nor for at least the foreseeable future, as ELF has not been sufficiently studied and described, and because ELF remains so diverse that it is questionable whether it can even be called a variety of English. Gnutzmann and Intemann (2005: 17) express similar resentments when they say that "the use of ELF is as diverse as the competences of its speakers are" and conclude that "[1]inguistic evidence for ELF as a variety seems to be scarce so far". With ELF not or not yet being an option, the demand for a heightened role of varieties in the ELT classroom currently seems to be the most promising way to provide learners of English with an education which gives them the maximum possible communicative competence.

This general demand for a more elaborate attention to varieties in ELT should be specified separately for the various levels of linguistic analysis, i.e. for grammar, pronunciation and vocabulary. There have recently been attempts to address the issue of pragmatic variation with respect to ELT as well (cf. Barron 2005; Barron and Schneider 2008), but this would 
have to be the topic of a separate investigation. While formulating these demands, we should keep in mind, however, that there are usually only a few weekly lessons devoted to ELT in institutionalized settings such as in secondary schools.

From the point of view of communicative competence, varieties of English are generally thought to differ least at the level of grammar (Trudgill and Hannah 2002: 18; Jenkins 2003: 74), implying that the grammatical differences between varieties of English do not have to be addressed extensively in the English language classroom, particularly not at the beginning and intermediate stages.

The situation is completely different with respect to pronunciation. Starting at an early age, learners should get broad receptive training and should be confronted with as many accents as possible (cf. Görlach 1999: 18), progressing from the most common to the least frequently used pronunciation varieties. From a communicative point of view, it is important to enable 21st century learners of English to understand a variety of accents so that they can effectively communicate with most speakers of English. At the same time, such receptive training will create awareness among learners that English, most likely just like their mother tongue, is not monolithic. As far as production is concerned it seems to be sufficient, again from a communicative point of view, to train learners to be able to produce any widely understood accent of English. Being able to produce or imitate different accents of English does not benefit learners' communicative competence.

At the lexical level, learners should also receive broad receptive training and should be confronted with a number of different varieties from an early age, to enable them to understand speakers from different geographical and social backgrounds and to increase awareness that there is a considerable amount of variation in language use in English. Receptive training at the lexical level should certainly start with, but not be limited to, the most common standard varieties. However, not everybody will agree with Görlach (1999), who takes the issue a step further when he demands that the confrontation with varieties should include material from "the periphery", arguing as follows:

If the teachability of Shakespeare's plays has never been questioned even though the language employed is pretty useless for modern communication, then there is no doubt 
that short texts from Scots, AmBlE [American Black English] and IndE etc. can be taught, too.

As far as vocabulary is concerned there should also be a certain amount of variety-related productive training, particularly at the intermediate and advanced level, to enable learners to communicate with speakers from different backgrounds. Such training also helps to increase learners' awareness that a certain amount of knowledge about varieties is necessary to be able to communicate effectively in English in speech and writing, and that communication has to be geared to their recipients' backgrounds to avoid misunderstandings and communicative breakdown.

In this section it has been shown that there is a need to include more exposure to varieties and variety-related training in ELT to create awareness that English is not monolithic and to provide learners with communicative competence that enables them to effectively communicate in a variety of situations in a changing and increasingly globalized world. Fortunately, we can draw on a growing number of current and systematic linguistic descriptions of varieties of English (e.g., Kortmann and Schneider 2004; Labov, Ash and Boberg 2005; Schneider 1997a,b), textbooks addressing varieties of English (e.g., Trudgill and Jannah 2002; Bauer 2003; Jenkins 2003; Burridge and Kortmann 2008; Kortmann and Upton 2008; Mesthrie 2008; Schneider 2008), and an increasing number of English-language corpora of authentic language data, such as the International Corpus of English (ICE) and the British National Corpus (BNC).

\section{The role of varieties of English in curricula, teaching material and university programs for prospective teachers}

We have seen in the previous section that varieties are, or at least should be, an important element of ELT at the beginning of the twenty-first century. For this study, I analyzed selected ELT curricula, teaching material and university programs for prospective teachers of English in Germany. The first step was to analyze the recently introduced new curricula for ELT at two types of secondary schools in the German state of Bavaria, namely the Realschule [year 5-10] and the Gymnasium [year 5-12], in terms of demands concerning varieties of 
English. The next step was to analyze the Klett-published textbook series Red Line New [for Realschule] and Green Line New [for Gymnasium] in terms of their treatment of varieties of English, and to compare the results to the variety-specific demands in the underlying curricula, keeping in mind that many teachers consider the textbooks the so-called "secret curriculum". Last but not least, two programs for prospective teachers at two German universities in two different states, namely the Catholic University of Eichstätt-Ingolstadt in Bavaria and the Johann Wolfgang Goethe-University of Frankfurt in Hesse, were screened for the status of varieties of English in the course of the program. The analyses of the curricula, the textbook series and the university programs were based on three questions:

(i) What role do varieties play in current curricula?

(ii) How do the accompanying textbook series reflect variety-specific demands in the curricula?

(iii) What kind of mandatory variety-related training do prospective teachers of English have to go through?

\subsection{Realschule: Curriculum and textbooks}

As already mentioned in section 2, the introductory section of the curriculum for the subject English at the Realschule emphasizes that "[i]nternationally, English is the most important second language and lingua franca" (BMUK 2000-2003: 52, my translation), which implies that the actual curriculum should reflect this sentiment by the inclusion of varieties of English at all stages as demanded in section 2 of this paper. A year-by-year analysis of the curriculum and textbook series yielded some interesting results. For year five, no inclusion of varieties could be detected in either the curriculum or the accompanying textbook Red Line New 1. For year six, the curriculum contains only one general remark at the very beginning, stating that students should be informed about the existence of varieties. The curriculum does not mention knowledge of features of varieties or learning about potential structural differences between varieties. In the accompanying textbook Red Line New 2, varieties do not occur at all, with the exception of a few words marked "AE" for American English in the vocabulary section at the end of the book, such as movie (Red Line New 2:154) and cellphone (Red Line New 2:155).

For year seven, there are no variety-related demands in the curriculum at all, whereas the textbook Red Line New 3 at least includes one listening comprehension exercise concerning 
accents from 4 major regions of the United Kingdom, namely England, Scotland, Wales and Northern Ireland (Red Line New 3: 9).

The curriculum of year eight demands that learners be shown "the peculiarities of American English" (BMUK 2000-2003: 310, my translation). However, the curriculum then goes limits this aim to receptive abilities at the level of listening and to the understanding of texts that contain features of American English, including American English vocabulary (BMUK 20002003: 310-311). The inclusion of varieties in the curriculum of year eight at first glance sounds like a step in the right direction, but we have to take into account that there are only three weekly English lessons of 45 minutes each at the Realschule in year eight, which means that we can expect that there is most likely very little time for the coverage of American English. This expectation is confirmed by the analysis of the accompanying textbook Red Line New 4, which contains only very few explicit references to American English. There are only two basic exercises comparing British English and American English in the whole textbook (Red Line New 4: 17, 46), and two boxes with comparisons of features of British English and American English - for the most part lexical and spelling differences - in the vocabulary section at the end of the book (Red Line New 4: 112, 139).

The curriculum of year nine demands that learners should be trained to understand texts that "contain features of different varieties of the global language English (e.g., Asia, Africa)" (BMUK 2000-2003: 408, my translation). Again this sounds like a step in the right direction, but as in year eight there are only three weekly English lessons in year nine and a multitude of other issues also have to be covered, which means that there is most likely not much time for varieties. The textbook Red Line New 5 reflects this situation by devoting only rather limited room to varieties. There is a minor listening exercise requiring learners to identify speakers of Indian English and British English (Red Line New 5: 24), a recording of a story about life in South Africa (Red Line New 5: 42-43), and a short recording of a conversation between a taxi driver from Trinidad and a passenger from Britain (Red Line New 5: 57). Only the exercise on page 24, however, focuses on the language use of regional varieties of English.

The last year at the Realschule, year ten, focuses on the preparation for the final schoolleaving exam, as explicitly stated in the introductory paragraph of the curriculum of this year (BMUK 2000-2003: 508). This means that year ten is dominated by teaching to the test, an 
exam in which varieties do not play an important role. The curriculum also demands that learners "encounter and understand additional varieties of English as a lingua franca" but does not specify this requirement any further (BMUK 2000-2003: 509, my translation). The textbook Red Line New 6 reacts to this demand by brief coverage of Canadian English, Australian English and New Zealand English. There are a few variety-related recordings on the $\mathrm{CD}$ accompanying the textbook, namely one example of a conversation between a British girl and two Canadians (Red Line New 6: 23) and a few short passages for listening that are read by speakers of Australian English and New Zealand English (Red Line New 6: 60-61). The only exercise specifically concentrating on variation in language use, however, is a task aimed at the identification of English speakers from Australia, Britain, India and the United States (Red Line New 6: 67). In the vocabulary section at the end of the book, there is a box with fifteen so-called "Australian and New Zealand words" (Red Line New 6: 145). However, the phonetic transcription of $G^{\prime} d a y$, which is often considered the signature feature of Australian English, is given in Received Pronunciation (Red Line New 6: 140).

Summing up the analysis of the curriculum for the Realschule and the accompanying textbook series Red Line New with respect to questions (i) and (ii) posed at the beginning of this section, we can conclude that there are number of steps in the right direction of raising awareness and introducing students to distinct varieties of English. This holds true particularly as far as variety-related demands in the curriculum are concerned, where varieties are given some attention in years eight, nine and ten. Despite these demands in the curriculum, rather little room is devoted specifically to varieties in the textbook series Red Line New. We cannot blame the textbooks alone, however, but should for the most part blame the fact that there are not sufficient weekly lessons of English at the Realschule, particularly when considering the status of English as a global means of communication (cf. Ammon 2008: 12-18 on the current importance of English in the world). The lack of a sufficient number of lessons (i.e. a sufficient amount of time) is certainly a key factor contributing to a weak representation of varieties in the textbooks and, as is presumed, a fairly limited consideration of varieties in day-to-day teaching, despite some ambitious demands in the curriculum. 


\subsection{Gymnasium: Curriculum and textbooks}

The curriculum for the Gymnasium is characterized by a strong focus on the United Kingdom and the United States, and their associated standard varieties of English, which is emphasized in the general remarks about the profile of the subject English at the beginning of the curriculum. Differentiated socio-cultural knowledge about the United Kingdom and the United States is said to be "at the center" of the subject English at the Gymnasium (BMUK 2004-2007: subject profile, my translation). As far as language is concerned, British English and American English are the only accepted norms, other varieties only play an explicit role with respect to listening comprehension:

The subject [English] is based on the standard language; British English and American English are equally accepted as norms. As far as listening comprehension is concerned, the students should also encounter important regional and social varieties of English.

(BMUK 2004-2007: subject profile, my translation)

The year-by-year analysis of the curriculum for the Gymnasium and the accompanying textbook series Green Line New also yielded some interesting results. In the curriculum of year five, varieties are not represented at all. The textbook Green Line New 1 does contain two pages on "English - a world language" (Green Line New 1: 98-99), providing mostly geographical information about the distribution of English as a world language. There are also a few words labeled "American English" in the vocabulary section at the end of the book, such as American English fries versus British English chips (Green Line New 1: 192).

For year six, the curriculum mentions in the section on pronunciation and intonation that students should encounter some easy-to-understand regional varieties (BMUK 2004-2007: year six). The analysis of the textbook Green Line New 2 revealed only one box with a comparison of vocabulary differences between British English and American English, many of which differ only in spelling (Green Line New 2: 173).

Similar to the curriculum of year six, the curriculum of year seven states in the section on pronunciation and intonation that students should encounter "more regional varieties" without being more specific (BMUK 2004-2007: year seven, my translation). The textbook does 
address varieties on two occasions, but instead of including other regional varieties, as demanded in the curriculum, it contains one exercise that asks students to identify speakers as either using British English or American English (Green Line New 3: 57), and a box with a list of British English and American English words, some spelling differences and three pronunciation differences (Green Line New 3: 154). As with year six, the textbook does not appear to contain material concerning "regional varieties".

For year eight, the curriculum demands that students should be trained to be able to identify "typical features of British and American pronunciation" (BMUK 2004-2007: year eight, my translation). Unfortunately, other varieties of English are not represented in the section on language in the curriculum of year eight, although some of the topics in the section on intercultural learning would provide the ideal framework for introducing new varieties to learners. The section on intercultural learning specifically demands that learners get to know the "situation and way of life of young people in another English-speaking country (e.g., Australia, Canada)" (BMUK 2004-2007: year eight, my translation). The textbook Green Line New 4 for year eight reflects the demand in the curriculum for a comparison of British and American pronunciation by a single exercise on differences between British English and American English, which does not even focus on pronunciation and includes all "four areas of language" (Green Line New 4: 83). The textbook does briefly make the connection between the cultural studies topic Australia and Australian language use by presenting some vocabulary items which are considered to be typically Australian, such as G'day and barbie ("barbeque"), but does not mark them as Australian English in the vocabulary section (Green Line New 4: 8, 124, 126). On the whole, varieties of English play hardly any role in year eight.

The focus of the curriculum of year nine is still on British English and American English. According to the curriculum, learners should be trained to be able to understand texts that are primarily spoken in Standard British English and Standard American English (BMUK 20042007: year nine, my translation). The curriculum also demands that students should encounter "additional regional and social varieties" without being more specific (BMUK 2004-2007: year nine, my translation). The textbook Green Line New 5 for year nine reflects the lack of specific instructions concerning varieties by not including explicit references to variation in 
language use at all, except for a few words labeled "American English" in the vocabulary section (e.g., Green Line New 5: 128).

The curriculum of year ten demands the inclusion of more regional and social varieties by means of authentic audio and video material. Unfortunately, the curriculum is so new that the accompanying textbook has not yet been published. However, if Green Line New 6 is in line with the other textbooks of the series, it may again not adequately reflect the variety-related demands of the curriculum. The curricula of years eleven and twelve so far exist only as rough drafts that contain just a few references to varieties, exclusively in the area of listening comprehension.

As noted above with regard to the Realschule, there are some steps in the right direction as far as varieties of English are concerned in the curriculum for the Gymnasium, but the varietyrelated demands are rather vague throughout the curriculum and varieties play a considerably smaller role than they do in the case of the Realschule. The curriculum contains specific instructions concerning varieties only for years eight and ten, with vocabulary differences only being included in year eight and only for British English and American English. The curriculum and textbooks for the Gymnasium, which are brand-new and will thus most likely last well into the second decade of the $21^{\text {st }}$ century, are somewhat anachronistic by almost exclusively focusing on British English and American English. In both the curriculum as well as the textbooks there is generally very little room devoted to varieties, again not reflecting the status of the English language today (cf. Ammon 2008: 12-18).

\subsection{Teacher training programs}

The role of varieties in day-to-day teaching in the classroom does, of course, also depend to some extent on the teacher. This is why two university programs for prospective teachers at the Realschule and Gymnasium in two different states were reviewed for this paper, namely (i) the program at the Catholic University of Eichstätt, and (ii) the program at the JohannWolfgang-Goethe University Frankfurt. Both programs include, among other things, classes concerning practical language skills, usually taught by native-speakers with either a British or an American background, and basic linguistics classes. The relevant departments of English linguistics at both universities offer seminars on varieties of English on a more or less regular basis, but these classes are by no means mandatory and only a small number of the students 
attends such a class in the course of their studies. We can only conclude that varieties unfortunately do not receive enough attention in university programs for prospective teachers and thus teachers are frequently not adequately prepared for addressing or coping with variety-related issues in the classroom. Lack of appropriate training and the resulting linguistic insecurity of teachers with respect to varieties may at least to a certain extent be responsible for the way in which many teachers treat varieties other than Standard British English, namely as "deviations" from what they consider "correct English". There is also a certain amount of hesitation among teachers to include varieties of English in ELT as this implies acceptance of a more complex pattern of language use, which makes straightforward right vs. wrong answers in the grading of exams rather problematic. Last but not least, varieties are frequently not considered important by teachers, as they usually do not play a major role in important exams.

In this section the example of Germany has made it clear that varieties are still not adequately represented in current English curricula, accompanying teaching material and university programs for prospective teachers, especially in light of the status of English in the world and the amount of variation learners of English will likely encounter outside their secondary school environment. The following section will be concerned with the question of how the use of more varieties in ELT can be implemented.

\section{The implementation of more varieties in ELT}

The previous sections have made it clear from a linguistic as well as a pedagogical point of view why we need to include more varieties of English in ELT in a more effective manner. The question remains as to how this can be done, especially without making naive demands and in consideration of the existing framework of the education system. The following suggestions could be among the necessary steps in the right direction.

Firstly, curriculum designers need to recognize the position of English in our changing world and the fact that the global spread of English has made the language and issues around its use more complex. The role of native and non-native varieties has to be strengthened in curricula and more time has to be devoted to English lessons to give teachers the opportunity to include teaching on varieties in the classroom; three times 45 minutes a week, as in years eight and 
nine of the Realschule, is simply not enough and does not do justice to the importance of English (cf. Ammon 2008: 12-18). It is, however, not enough to simply include ambitious demands concerning varieties in the curriculum and to devote more time to English learning it also has to be ensured that the accompanying textbooks adequately reflect these demands.

A second important and necessary step would be to begin curriculum-based ELT at an earlier age. In the case of the German state of Bavaria, and in fact in all states of Germany, primary school learners do receive foreign language instruction, usually English, some from year one and some from year three. However, the content of such lessons depends largely on the selection of the teacher since curricula are either vague or have not yet been established. This means that the intake of secondary schools is extremely heterogeneous with regard to previous knowledge of English and as a result English instruction at the secondary level usually has to start from scratch in year five. In order to make English learning in primary school worthwhile, curricula for English learning at primary school level would need to be introduced in all states as soon as possible (cf. Klippel and Doff 2007: 25). This would automatically provide two to four more years of meaningful English learning and at the same time free up instruction time for varieties of English. Since the system of English language education in primary schools is already in place, sticking to the current curriculum-free approach would mean a lost opportunity.

A third essential step for the implementation of more varieties in ELT would be the introduction of adequate and mandatory variety-related training of prospective and active teachers. Variety-related training must be provided to keep already active teachers up to date, because teaching "the same old same old" for many decades after having left university cannot be an option in a world constantly changing at an increasing pace. For prospective teachers, it would be necessary to make adequate variety-related training a mandatory part of English programs at universities.

\section{Conclusion}

Summing up the findings of this paper, it seems safe to conclude that varieties of English are still not adequately represented in current ELT, as has been demonstrated with the help of an example from Germany in section 3. Analyses of ELT curricula, teaching materials and 
teacher training programs elsewhere would probably differ concerning certain details, but the basic findings of this exploratory study will most likely hold true for ELT in many other countries and territories. Referring back to the two main research questions underlying this paper (cf. section 2), it has been shown that there is no alternative to an increased representation of varieties of English in ELT if we are serious about the main aim of communicative language learning, which is to enable learners to effectively communicate in a maximum of situations. Students should encounter as many varieties as possible, develop an awareness of linguistic diversity and learn systematically about how varieties can differ from each other in order to lay the foundations for life-long learning. It has to be pointed out to learners of English that the English language is not monolithic but a constantly evolving dynamic system with a pluricentric structure. Teachers, textbook authors, curriculum designers, foreign language education researchers, applied linguists, sociolinguists and other ELT-related experts should make good use of the growing body of systematic linguistic descriptions of varieties of English and work together to produce material that helps learners of English with learning about varieties and variation. These linguistic resources, however, have not yet received adequate attention by materials and curriculum developers. Finally, the suggestions in section 4 need to be implemented to make maximal use of the available resources, to give learners a meaningful English language education that prepares them for the sociolinguistic reality and thus the challenges of everyday life in a globalized world, and to provide teachers with the tools to help their students to achieve this goal. Despite some small steps in the right direction that have already been made, the current representation of varieties of English in ELT, and its distribution over the school years, can be summarized as follows: too little, too late. It is, however, certainly never too late to start developing, testing and implementing new ideas, some of which have been laid out in this paper.

\section{References}

Ammon, U. 2008. Fremdsprachengebrauch und -bedarf unter den Bedingungen der Globalisierung. Zeitschrift für Angewandte Linguistik 48: 3-27.

Barron, A. 2005. Variational pragmatics in the foreign language classroom. System 33(3): 519-536.

Barron A. and K. P. Schneider (eds). 2008. Variational pragmatics: A focus on regional varieties in pluricentric languages. Amsterdam and Philadelphia: Benjamins. 
Bauer, L. 2003. An introduction to international varieties of English. Edinburgh: Edinburgh University Press.

Bieswanger, M. 2007. Language and education. In M. Hellinger and A. Pauwels (eds). Handbook of language and communication: Diversity and change. Handbooks of applied linguistics 9. Berlin and New York: Mouton de Gruyter. pp. 401-427.

Bieswanger M. and A. Becker. 2008. Introduction to English linguistics. $2^{\text {nd }}$ edition. Tübingen: Francke.

Burridge, K. and B. Kortmann (eds). 2008. Varieties of English: The Pacific and Australasia. Berlin and New York: Mouton de Gruyter.

Center for Applied Linguistics. 2006. About CAL. http://www.cal.org/about/index.html. Accessed on 15 August 2006.

Cook, G. 2003. Applied linguistics. Oxford: Oxford University Press.

Clyne, M. (ed). 1991. Pluricentric languages: Differing norms in different nations. Berlin and New York: Mouton de Gruyter.

Crystal, D. 2002. The Queen and us. Spotlight 6(2): 18-22.

Crystal, D. 2003. English as a global language. $2^{\text {nd }}$ edition. Cambridge: Cambridge University Press.

Doughty, C. and J. Williams (eds). 1998. Focus on form in classroom second language acquisition. Cambridge: Cambridge University Press.

Görlach, M. 1999. Varieties of English and language teaching. In C. Gnutzmann (ed). Teaching and learning English as a global language. Tübingen: Stauffenberg. pp. 321.

Gnutzmann, C. 2005. 'Standard English' and 'World Standard English'. Linguistic and pedagogical considerations. In C. Gnutzmann and F. Intemann (eds). The globalisation of English and the English language classroom. Tübingen: Narr. pp. 107-118.

Gnutzmann C. and F. Intemann. 2005. Introduction: The globalization of English. language, politics, and the English language classroom. In C. Gnutzmann and F. Intemann (eds). The globalisation of English and the English language classroom. Tübingen: Narr. pp. 9-24.

Hickey, R. (ed). 2004. Legacies of colonial English. Studies in transported dialects. Cambridge: Cambridge University Press. 
Hughes, A., P. Trudgill and D. Watt. 2005. English accents and dialects: An introduction to social and regional varieties of English in the British Isles. $4^{\text {th }}$ edition. London: Arnold.

Hymes, D. 1972. Models of the interaction of language and social life. In J.J. Gumperz and D. Hymes (eds). Directions in sociolinguistics: The ethnography of communication. New York: Holt. pp. 35-71.

Jenkins, J. 2003. World Englishes: A resource book for students. London: Routledge.

Jenkins, J. 2005. Teaching pronunciation for English as a lingua franca: A sociopolitical perspective. In C. Gnutzmann and F. Intemann (eds). The globalisation of English and the English language classroom. Tübingen: Narr. pp. 145-158.

Klippel, F. and S. Doff. 2007. Englischdidaktik: Praxishandbuch für die Sekundarstufe I und II. Berlin: Cornelsen.

Kortmann, B. and C. Upton (eds). 2008. Varieties of English: The British Isles. Berlin and New York: Mouton de Gruyter.

Kortmann, B. and E. Schneider (eds). 2004. Handbook of varieties of English. Berlin and New York: Mouton de Gruyter.

Labov, W., S. Ash and C. Boberg. 2005. Atlas of North American English. Berlin and New York: De Gruyter.

McArthur, T. 1998. The English languages. Cambridge: Cambridge University Press.

McArthur, T. 2001. World English and world Englishes: Trends, tensions, varieties, and standards. Language Teaching 34: 1-20.

Mesthrie, R. (ed.) 2008. Varieties of English: Africa, South and Southeast Asia. Berlin and New York: Mouton de Gruyter.

Schneider, E.W. (ed). 1997a. Englishes around the world: Studies in honour of Manfred Görlach - Volume 1: General studies, British Isles, North America. Amsterdam: Benjamins.

Schneider E. W. (ed). 1997b. Englishes around the world: Studies in Honour of Manfred Görlach - Volume 2: Caribbean, Africa, Asia, Australasia. Amsterdam: Benjamins.

Schneider E. W. (ed). 2008. Varieties of English: The Americas and the Caribbean. Berlin and New York: Mouton de Gruyter.

Seidlhofer, B. 2005a. English as a lingua franca. ELT Journal 59: 339-341.

Seidlhofer, B. 2005b. Standard future or half-baked quackery? Descriptive and pedagogical bearings on the globalisation of English. In C. Gnutzmann and F. Intemann (eds). The 
globalisation of English and the English language classroom. Tübingen: Narr. pp. 159-173.

Trudgill, P. and J. Hannah. 2002. International English: A guide to the varieties of standard English. $4^{\text {th }}$ edition. London: Arnold.

Viereck, W., K. Viereck and H. Ramisch. 2002. Dtv-Atlas Englische Sprache. Munich: Dtv.

\section{Curricula}

BMUK (Bayerisches Ministerium für Unterricht und Kultus). 2000-2003. Lehrplan Realschule (R6). Munich: Maiss.

BMUK (Bayerisches Ministerium für Unterricht und Kultus). 2004-2007. Lehrplan Gymnasium (G8). Wolnzach: Kastner.

\section{Secondary School Textbooks}

Red Line New 1-6. Stuttgart: Klett

Green Line New 1-5. Stuttgart: Klett 